\title{
A Case Study of Non-Violent Property Crime Victimisation in a South African Urban Residential Neighbourhood: Exploring the Excessive Use of Force and Destruction Caused by Burglars to Gain Entry to Victims' Properties
}

\author{
Johan van Graan*
}

\section{Department of Police Practice, University of South Africa, Pretoria, South Africa}

\begin{abstract}
Commentators frequently report on the high prevalence of violent crime in South Africa and often label the country as one of the most violent in the world, with a subculture of violence and criminality. This paper focuses on a different perspective, reporting on the excessive use of force and destruction caused by offenders in South Africa to gain entry to victims' properties in the execution of non-violent property crimes, in a particular residential burglary. Literature on property crimes has been considering the aggravating circumstances of violent property crimes. However, the use of excessive force and destruction caused by burglars to gain access to victims' properties in the execution of residential burglary remains relatively untested in the literature. In this light, the purpose of this study is to describe the unprecedented levels of force used and destruction caused by burglars to gain access to victims' properties during residential burglary victimisation in an urban residential neighbourhood in Johannesburg, South Africa. A qualitative research approach is followed. A case study design was used to select an urban residential neighbourhood in Johannesburg as a case study. A data set of $(n=1431)$ crimes were purposively selected by means of non-probability sampling. Qualitative and quantitative content analysis was used to analyse the data. This paper offers valuable insight into the forceful and destructive conduct of burglars in the selected neighbourhood and contributes to the body of knowledge by providing an improved understanding of target hardening as a preventive measure against residential burglary victimisation as well as on methods of entry used by burglars in incidents of residential burglary. The results of reported non-violent property crime victimisation incidences by this community's neighbourhood watch scheme suggest that residential burglars in the selected neighbourhood are uncharacteristically forceful and ravage in their actions since they frequently revert to extreme use of force and destruction, disproportionate to the crime perpetrated. It is concluded that this radical degree of force used and destruction caused by residential burglars to gain entry to victims' properties in the execution of non-violent property crimes is not typically associated with residential burglary as compared to countries internationally.
\end{abstract}

Keywords: Property crime, residential burglary, South Africa, target hardening, use of force, victimisation.

\section{INTRODUCTION}

Non-violent property crime perpetrated in urban residential neighbourhoods in South Africa remains alarmingly high and by far outnumbers other crime categories. Property crime is acknowledged as the major type of crime worldwide (Sheu and Chiu 2012; Mustaine and Tewksbury 1998; Fox and Farrington 2012; Bond and Hajjar 2013). The most predominant property crimes affecting South African households, as published in the South African Police Service (SAPS) Annual Crime Statistics for 2019/2020 (South Africa 2020a), 2018/2019 (South Africa 2019a) and 2017/2018 (South Africa 2018), are burglaries at residential premises (205 959; 220 865; 228 094), theft of motor vehicles and motorcycles (46 921; 48 324; 50 663), and theft out of or from motor vehicles (118 213; 125 076; 129 174) respectively. According to the 2019/2020 Victims of Crime Survey (VOCS) (South Africa 2020b), an estimated 1,2 million incidences of residential burglary occurred, affecting 891000

*Address correspondence to this author at the Department of Police Practice, University of South Africa, Pretoria, South Africa; E-mail: vgraajg@unisa.ac.za households in South Africa. The number of affected households represents 5,3 percent of all households in the country. Almost 52 percent of households that experienced residential burglary reported it to the police. Burglary continued to be the dominant type of crime in 2017/18, accounting for 54 percent of all household crimes surveyed in the VOCS. An estimated 832122 incidences of burglary occurred, which is a 7 percent increase compared to the previous year (South Africa 2018). In 2014/15, each day, on average, 151 vehicles were stolen. Theft of motor vehicles decreased by 2.7 percent in 2014/15 when compared to $2013 / 14$. According to the $2013 / 14$ VOCS, reporting rates dropped from 98.2 percent in 2010 to 92.7 percent in 2013/14. Theft out of motor vehicles increased by 1.1 percent to 145358 incidents in 2014/15. Each day, on average, 398 vehicles were broken into and property stolen.

The SAPS distinguishes between contact crime, contact-related crime, and property crime (South Africa 2015), among others, as crime categories. Property crime is primarily classified as "violent" and "nonviolent" property crime. Violent property crime 
(categorised by the SAPS as "robbery with aggravating circumstances") involves the use of physical force against a person to take their property and is usually accompanied by physical injury to a person, for example, carjacking and house robbery (home invasion). Non-violent property crime involves the taking of property and does not involve force or threat of force against a victim, such as residential burglary and motor vehicle theft. Robberies with aggravating circumstances are thus both property crimes and violent crimes. They are, therefore "violent property crimes".

However, what makes South Africa's non-violent property crime problem unique is not as much the high frequency of non-violent property crime victimisation as it is the "extraordinary" levels of force and destruction used by offenders to gain access to victims' properties during the execution of these crimes, thus greatly affecting public safety and the fear of crime. In this light, the rationale of conducting this study is to explore and describe the unprecedented forceful and destructive conduct of burglars in South Africa to gain access to properties to commit residential burglary in the selected neighbourhood. Research on property crimes has given more attention to the aggravating circumstances of violent property crimes. However, the use of excessive force and destruction caused by burglars to gain access to victims' properties in the execution of residential burglary has not received similar attention resulting in the need to conduct this research. The need for this study was further motivated because of the dearth of available data on the methods that residential burglars use to enter victims' properties as well as limited research conducted on target hardening measures used to mitigate property crimes.

The author hypothesises, firstly, that the increased effort needed by an offender to commit non-violent property crime in South Africa, as a result of intensified target hardening preventive measures implemented by the vast majority of households due to widespread and recurring property crime victimisation, in effect, motivates perpetrators to resort to radical use of force and destruction to gain access to victims' properties in order to overcome reinforced target hardening measures. Secondly, social and economic factors, such as poverty and high unemployment rates in South Africa, contribute to offenders' determination to successfully execute non-violent property crimes, to such an extent, that they are prepared to resort to extreme force and destruction to overcome target hardening measures to enter victims' properties.
Thirdly, victims of urban residential burglaries are from varied geographic locations, socio-economic background, race and gender; thus, every household is at risk and a potential burglary victim.

The aim of this paper is to describe the unprecedented forceful and destructive conduct of burglars to gain access to properties to commit residential burglary in the selected neighbourhood. The author contextualises the relationship between violent property crime and non-violent property crime from a South African perspective, describe the nature and extent of non-violent property crimes in the country, provide a brief historical background and improved understanding of violence and crime in South Africa, and provide an international overview of target hardening as a preventive measure against residential burglary victimisation. In addition, available literature on methods of entry used by burglars in incidents of a residential burglary in various countries is presented. Finally, insight into the forceful and destructive conduct of burglars in the selected neighbourhood is provided.

The author acknowledges, first, that the high frequency of non-violent property crime victimisation, in particular residential burglary, is a global phenomenon and not exclusive to South Africa. Second, non-violent property crime victimisation is generally associated with some degree of force and damage to gain access into a property. Third, both area and individual characteristics play an important role in determining the likelihood of property crime victimisation (Trickett, Osborn, and Ellingworth 1995; Tseloni 2006; Pitcher and Johnson 2011), and exposure to crime is unevenly distributed within a population, and across different neighbourhoods (Estrada and Nilsson 2008).

The author makes one principal argument: Nonviolent property crime victimisation, which is generally associated with some degree of force used and damage caused, in a particular burglary at residential premises, that is perpetrated in South African urban residential neighbourhoods, is particularly forceful since offenders very often revert to extreme force and destruction to overcome target hardening measures in the execution of residential burglary to gain entry to victims' properties. It is further argued that this exceptional degree of force and destruction in the execution of residential burglary is not typically associated with residential burglary compared to the available literature on property crime victimisation internationally. 


\section{HISTORICAL CONTEXT OF CRIME AND VIOLENCE IN SOUTH AFRICA}

In an attempt to contextualise the forceful and destructive conduct of offenders gaining entry to victims' properties during residential burglary victimisation, the author deems it important to provide perspectives on the nature and extent of crime and violence in South Africa which will contribute to an improved understanding of the forceful and destructive nature of residential burglary.

Why is the incidence of crime and violence in South Africa so high? According to Gould (2014), one should look at the country's (political) history to understand the extent of violence and crime in South Africa. Gould considers the approach the country followed in dealing with its violent past, increasing poverty and inequality, and failure as a country to secure confidence in and respect for the rule of law as primary reasons for South Africa's extreme violence and crime. The findings of a report by the Centre for the Study of Violence and Reconciliation (CSVR) (SA's violent crime has roots in apartheid, says report 2011) on the investigation into the causes and nature of violent crime in SA, found that apartheid emerged as one of the key contributors to the high level of violent crime. This report further considers previous state policies that exposed millions of boys and young men to humiliating police harassment and a violent prison system during the apartheid years as one of the reasons for violent crimes in the country. The rule of law was also undermined by the state sponsorship of township violence during that time. These uniquely South African issues nurtured a culture of violence that has reproduced itself ever since. The report further adds, "the psychological legacy of institutionalized racism in the form of internalized feelings of low self-worth is likely therefore to be a contributing factor to the problem of violent crime in South Africa". Moreover, the lack of proper policing in townships during the apartheid years also gave rise to the culture of violence that South Africans continue to experience to this day. The report also identified ambivalent attitudes regarding crime, law, and the normalisation and widespread tolerance of violence as a critical issue. This reflects widely held norms and beliefs, which see violence as a necessary and justified means of resolving conflict or other difficulties.

Alluding to other reasons for crime and violence in South Africa, the report also found that the core problem of crime in the country was a subculture of violence and criminality. This subculture is characterised by young men "invested in a criminal identity and engaged in criminal careers" that involves active criminal lifestyles. Another feature of this subculture was the common use of weapons. "The ability to operate and achieve credibility within this subculture is strongly related to one's readiness to resort to extreme violence using a weapon," the report adds. The importance of weapons in this subculture was identified as a key driver behind the problem of armed violence in the country. "Violent offenders who engage in armed violence present the most danger to others and are what gives the current epidemic of violent crime in South Africa its most malevolent edge," the report notes. In addition, the report notes the high level of inequality in the country, which also contributes to the violence. Statistics reveal that in 2008, the richest 10 percent of households in South Africa earned nearly 40 times more than the poorest 50 percent. According to international research, societies with high levels of inequality tend to have high levels of violence - an indication that inequality is also a key driver of violence. According to Statistics South Africa's Quarterly Labour Force Survey released on 23 June 2020 , the unemployment rate in South Africa was 30,1 percent in the first quarter of 2020 (South Africa 2020d).

It is well recognised that unemployment can be implicated in both the demand (motivation) and supply (opportunity) functions for property crime victimisation (Kleck and Chiricos 2002). In support of Kleck and Chiricos, Tseloni and Farrell (2002) specify a greater risk of burglary victimisation for households residing in countries characterised by high levels of urbanisation and high unemployment rates. These measures indicate an increase in the opportunities for motivated offenders and suitable targets to converge. Further evidence was found of a positive link between unemployment and property crime victimisation (Edmark 2005; Nilsson and Agell 2003) as well as poverty that could motivate a potential offender (Chon and Wilson 2016). Van Wilsem, de Graaff and Wittebrood (2003) propose societies characterised by an unequal distribution of material resources will have an influx of motivated offenders. Based on Bennett's (1991) supposition that the level of inequality of a nation can be a necessary, although not sufficient, condition for the desire to steal, Stein (2010) believes inequality is linked to property crimes, where the goal is material gain.

From the literature, as presented in paragraph 2 above, South Africa's (political) history, a subculture of 
violence and criminality, confidence in and respect for the rule of law as well as high levels of inequality in the country emerged as primary contributing factors and key drivers for the high rate of crime and violence. South Africa became a democracy in 1994 creating a more stable political environment. However, high levels of inequality and unemployment still exist in the country. Given the high crime rate in South Africa, respect for the rule of law remains a concern. These factors thus suggest that if inequality, unemployment and respect for the rule of law could be addressed, crime and violence would decrease.

\section{PROPERTY CRIME VICTIMISATION AND THE FEAR OF CRIME}

South Africa is placed among the worst countries in the world for giving citizens a sense of safety, according to The Gallup Global Law and Order Report for 2015 (Gallup Global Law and Order 2015 Report 2015). This index ranks SA 138th out of 141 countries for its capacity to maintain law and order. The index gauges people's sense of personal security in their daily lives, as well as their personal experiences with crime and law enforcement. Of the South Africans surveyed, less than a third of people (31 percent) indicated they felt safe in the country. Hale (1996); Jackson (2006); Brunton-Smith and Sturgis (2011); and Lane and Fox (2013) confirm that fear is a rational reaction to the risk of criminal victimisation in the neighbourhood in which an individual lives and is viewed by the public as very problematic (Larsson 2009). Dull and Wint (1997) confirm that fear of crime could be drawn to property crime victimization. In support of Dull and Wint, Chon and Wilson (2016) found that property crime victimisation has consistent positive relationships with fear of crime. However, victims of these types of crimes are not always treated with the same level of sympathy as violent crime victims (Bond and Hajjar 2013). According to Sims, Yost and Abbott (2006), there is no doubt that experiencing a crime can have a debilitating impact on individuals. Although it would seem that victims of a violent crime would suffer more, both physically and mentally, than would a victim of a non-violent crime, evidence suggests that victims of some non-violent crimes do suffer. Sheu and Chiu (2012) concur that not only can property crime threaten the social order, but it also affects personal safety and wealth. Burglary victimisation, for example, can cause considerable fear among households and is one of the major concerns among the public (Markowitz, Bellair, Liska, and Liu 2001; Grabosky 1995).
Findings of the Positive Peace Report 2015 rate SA as one of the most violent and unsafe countries in the world (Institute for Economics and Peace [IEP], 2015). South Africa has dropped 14 places on the global ranking, from 122nd in 2014 to 136th in 2015. This places the country in the lower end of the region rankings, ranked 37th out of 44 Sub-Saharan African nations. As far back as 1990, many commentators have come to refer to South Africa as having a "culture of violence" - a society that endorses and accepts violence as an acceptable and legitimate means to resolve problems and achieve goals (Vogelman and Simpson 1990).

The literature, as presented in paragraph 3 above, clearly indicates that the high levels of non-violent property crime victimisation in SA, accompanied by the excessive use of force and destruction to gain access to victims' property, contribute to citizens' perceptions of the lack of safety and fear of crime. The literature further confirmed that fear is a rational reaction to the risk of criminal victimisation. However, victims of nonviolent property crimes are not always acknowledged with the same level of compassion as violent crime victims. Burglary victimisation in South Africa causes significant fear among households and has been found one of the major concerns among the public. Citizens fear of burglary victimisation are valid since South Africa is identified as one of the most violent and unsafe countries in the world.

\section{TARGET HARDENING AS PREVENTIVE MEASURE AGAINST PROPERTY CRIME VICTIMISATION}

Cornish and Clarke (2003) explain hardening targets as a preventive measure against property crime victimisation that includes, for example, the installation of locks, bolts, protective screens, and other physical barriers to obstruct an offender's access to a potential target. Clarke (1997) explains target hardening as an obvious, often highly effective way of reducing criminal opportunities to obstruct the vandal or the thief by physical barriers using locks, safes, screens or reinforced materials. According to Sanders, Kuhns, and Blevins (2017), such measures create more obstacles, which in turn lead to an increased perceived risk of a burglar and/or reduced likelihood of the event occurring. Although deliberate burglars are more likely to engage in creative techniques and use tools during their burglary, more often than not they will avoid unnecessary risks and attempt to locate a target with fewer obstacles to overcome (Sanders et al. 2017). 
According to Portland State University (2010), a burglar's selection of potential targets also reflects his or her desire to find the most accessible dwelling with easy entry and exit. Newton, Rogerson and Hirschfield (2008) explain "target hardening" as a term used to describe the process of increasing the security of a property to make it more difficult to burgle, thereby increasing the effort needed by the offender to gain entry to a property. However, FBI Statistics (U.S. Department of Justice 2013) indicate 59.2 percent of burglaries involve forced entry, regardless of which deterrent is used. Using double-paned windows, deadbolt locks, and reinforced doors, however, will increase the effort required to break-in as well as increase the perceived risk for the burglar. However, in his study, Sorensen (2003) conducted a comprehensive review of research in the United Kingdom and the United States and concluded that target hardening has substantial evidence confirming its effectiveness. Sorensen is further of the view that restricting access to the perimeter of a property could be expected to reduce the risk of burglary since it increases an offender's perceptions of the effort required to access the property itself. Moreover, it increases an offender's perception of the risk of being noticed, since residents will be more likely to recognise the presence of strangers in limited-access areas, and it increases an offender's perception of the risks and/or effort necessary to flee from a property if flight becomes necessary. Cornish and Clarke (2003) confirm target hardening is a well-established strategy within situational crime prevention. Target hardening has been employed internationally and has been widely cited as an effective strategy for burglary reduction (Weisel 2002; Hirschfield 2004; Millie and Hough 2004; Hamilton-Smith and Kent 2005; Newton et al. 2008). In addition, Bond and Hajjar (2013) confirm that effective strategies to reduce property crime include target hardening measures.

To illustrate South African households' response to the high levels of property crime victimisation, the VOCS 2013/14 (South Africa 2014) found that half of the households in SA took physical measures (target hardening) to protect their homes, while more than a quarter took measures to protect their vehicles. Approximately two-thirds of households in Gauteng and Western Cape (two of the most populated provinces) indicated that they took physical protection measures to protect their homes. According to the VOCS 2018/19 (South Africa 2019b), almost 32 percent of respondents took physical measures to protect their homes.
Skogan (1987) similarly found that victims of property crime engage in more target hardening precautions. In support of Skogan, various studies found that victims engage in more protective behaviour following victimisation, while other studies found the opposite result (Ferraro 1995; Rountree and Land 1996). Roh, Kim and Yun (2010) examined the effects of target hardening efforts on the street and residential crime victimisation and, unexpectedly, found that individuals who engaged in avoidance behaviours and target hardening efforts were more likely to be victims of both street and residential crime, perhaps because they were responding to prior victimisation. Kuo (2015) reports much literature has found that the more accessible a residence was, the more vulnerable it was to potential burglars, measuring accessibility in at least three different fashions: how easy a household could be entered and escaped, security devices, and occupancy.

In addition, Cromwell, Olson and Avary (1991) conducted interviews with 30 active burglars exploring physical accessibility to property and found that the presence of target hardening measures such as a watchdog, alarm systems, and security hardware was mainly effective to deter burglars. Ferraro (1995) further found that individuals who had experienced victimisation were more likely to own a watchdog. However, in an opposing finding, Robinson and Robinson (1997) found that security devices had a minimal effect on burglaries. Indermaur (1996) is of the view that advertising the fact that alarms can be raised instantaneously could make a target much less attractive to some thieves, although others may include the likelihood of an alarm sounding in their planning and still judge that the rewards outweigh the risks. The Concept Paper for the Justice, Crime Prevention and Security Cluster found that security measures that have contributed to target hardening, such as immobilisers and tracking devices on vehicles, alarms and security gates, and walls and fences on properties, are believed to have contributed to increased levels of violent crime in South Africa. Related to the fact that non-violent property crimes, such as residential burglary or motor vehicle theft, have become more difficult to execute as a result of increased target hardening measures, criminals are, in effect, encouraged to resort to violent property crime (robbery) where the threat of violence is used to overcome resistance (Centre for the Study of Violence and Reconciliation [CSVR] 2007). 
A literature review on target hardening measures used to mitigate property crimes in international countries has delivered marginal results. However, according to Altbeker (2005), the problem of missing data can be rectified by using data from countries that was obtained in earlier years, as illustrated below. As a result, the author drew on available literature on target hardening measures used in international countries to mitigate property crimes.

A victimisation survey that explored target hardening measures in thirteen African countries found an overwhelming majority (95.4 percent) of Namibian respondents have a burglar alarm. There were also above-average percentages of burglar alarm ownership in Swaziland (62 percent) and Lesotho (48.7 percent). Levels of ownership were very low in Mozambique (1.1 percent), Zambia (4.9 percent), and Zimbabwe (5 percent). Almost one-third (32.4 percent) of all respondents confirmed they had installed special door locks. Countries with high ownership of special door locks included Zimbabwe (44.2 percent), South Africa (41.6 percent), Zambia (41.2 percent), Uganda (32 percent), and Namibia (31.9 percent). The rate of special door locks was very low in Lesotho (5.8 percent), Swaziland (11.2 percent), and Mozambique (13.7 percent). Many households were equipped with high fences in Zimbabwe (52.7 percent) and South Africa (32.4 percent). High levels of membership informal neighbourhood watch schemes were reported in Namibia (67 percent), followed by Uganda (43.4 percent) and Nigeria (27.2 percent). Making use of watchdogs for the purposes of detecting and deterring potential burglars was a method employed mostly by households in South Africa (21.7 percent) and Zambia (17.3 percent) (Ladikos in Naudé, Prinsloo and Ladikos 2006). According to Altbeker (2005), these victimisation surveys sometimes offer the prospect of ascertaining the true level of crime, uncontaminated by the underreporting and under-recording problems that beset police crime statistics. When victimisation surveys use common definitions for crimes when they approach respondents in different jurisdictions, the results can serve as the basis for making cross-country comparisons.

Evidence from field studies conducted by Owusu, Wrigley-Asante, Oteng-Ababio and Owusu (2015) indicate that target hardening of houses is the dominant preventative measure applied in urban Ghana. Prominent among these target hardening measures are the use of metal burglarproof windows and doors, and high fence walls with (or without) barbed wire. These features have become associated with houses in middle- and upper-class residential areas. According to Adzande and Gyuse (2017), residents in the Nigerian city of Makurdi raise wall fences, often capped at the top with razor wire, to keep away intruders; install reinforced locks on doors and window grills; hire private security, and rely on neighbourhood watch groups for night-time patrols. In addition to these measures, residents of some streets have raised collective funds to erect street barricades and pay allowances to volunteers of the neighbourhood watch group. The gridiron street layout favours the construction of gates at designated entry and exit

Table 1: Target Hardening Measures Implemented in African Countries to Prevent Property Crime Victimisation

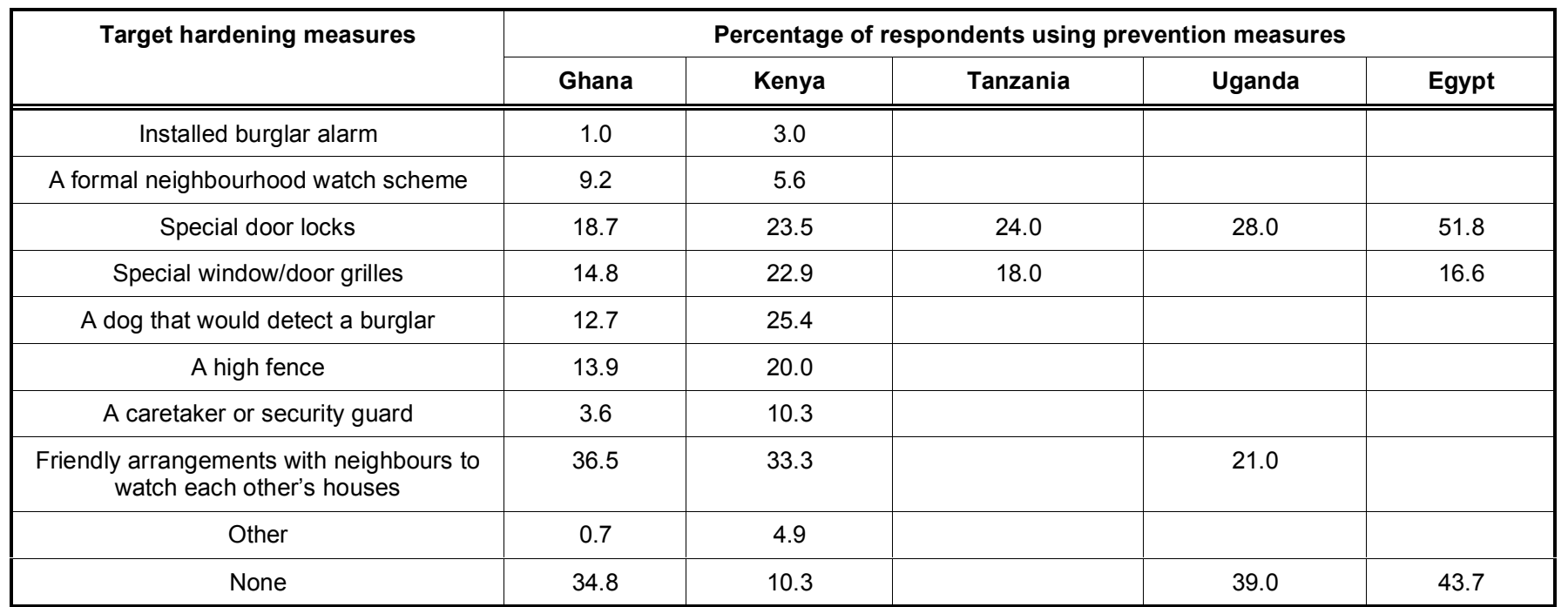

(Victimization Survey in Ghana 2010; Victimization Survey in Kenya 2010; Victimization Survey in Tanzania 2009; Victimization Survey in Uganda 2008; Victimization Survey in Egypt 2009). 
points. Also, in some residential areas, vigilante groups mount temporary street barricades every night to prevent the entry of potential offenders into neighbourhoods. The trend in middle- and high-income residential neighbourhoods has been to create personal territories by building high walls around individual residences. More recently, entire streets are barricaded with gates or bars at both ends to privatise streets as an attempt at crime prevention and safety.

In addition, Table $\mathbf{1}$ above illustrates target hardening measures implemented in Ghana, Kenya, Tanzania, Uganda and Egypt to prevent property crime victimisation.

In addition, available data on methods of entry used by burglars in incidents of residential burglary or attempted burglary internationally are also illustrated in Table 2 below to provide a further perspective on how target hardening measures are overcome or attempted to overcome in these countries. However, data on the methods residential burglars use to enter victims' properties also produced limited results.

Table 2 below illustrates the methods of entry to residences used by burglars in incidents of a residential burglary in England and Wales.
Table 3 below illustrates Australian household experiences of evidence of attempted burglary and whether property was damaged resulting from burglary incidents.

A study among victims of residential burglary in the Charlotte, North Carolina region in the United States of America (USA) indicated that most offenders entered the residence through some use of force (about 62 percent). Entry occurred primarily by breaking (24.1 percent or forcing open (15 percent a window or forcing a front (15 percent) or back door (21.4 percent) open (Kuhns, Blevins, and Turner 2016). Moreover, a survey conducted over three years between 2013 and 2016 in Berlin, Bremerhaven, Hannover, Munich and Stuttgart in Germany, revealed in 77.2 percent of the cases that the burglar broke or pried open a door or window. In a further 11.3 percent, glass was broken to enter the house. Damaging or manipulating the lock with a tool or false key only happened in 8.5 percent of the burglaries. Using an open or tilted window only occurred in 7.1 percent (Wollinger, Dreißigacker, and Baier 2017). In addition, the results of an international expert survey on organised residential burglary revealed that breaking into a property is often not different when committed by organised perpetrators or

Table 2: Method of Entry in Incidents of Residential Burglary in England and Wales from April 2014 to March 2018

\begin{tabular}{|c|c|c|c|c|}
\hline \multicolumn{5}{|c|}{ Residential burglary with entry } \\
\hline \multicolumn{5}{|l|}{ Percentage $^{1}$} \\
\hline Door & 71 & 75 & 75 & 67 \\
\hline Forced lock & 21 & 17 & 19 & 19 \\
\hline Pushed past person who opened the door & 8 & 7 & 10 & 8 \\
\hline False pretences & 3 & 3 & 7 & 4 \\
\hline They had a key & 8 & 11 & 9 & 6 \\
\hline Kicked, smashed or rammed door & 1 & 1 & 3 & 1 \\
\hline Window & 27 & 23 & 24 & 29 \\
\hline Forced window lock/catch & 11 & 8 & 8 & 8 \\
\hline Window open/could be pushed open & 12 & 7 & 10 & 11 \\
\hline Broke/cut glass & 5 & 9 & 6 & 8 \\
\hline Other method & 0 & 0 & 0 & 2 \\
\hline Other & 2 & 3 & 3 & 5 \\
\hline
\end{tabular}

Figures may not sum to 100 as more than one response is possible. (Crime Survey for England and Wales 2008-2018 2019). 
Table 3: Household Experience of Evidence of Attempted Burglary and whether Property was Damaged Resulting from Burglary Incidents in Australia

\begin{tabular}{|c|c|c|}
\hline \multicolumn{3}{|l|}{ Attempted burglary } \\
\hline & Households & Proportion \\
\hline & '000 & Percent \\
\hline \multicolumn{3}{|l|}{ Evidence of attempted burglary ${ }^{2}$} \\
\hline Door/window was damaged/tampered with & 96.5 & 47 \\
\hline Door/window was open when it should not have been & 17.8 & 8.7 \\
\hline Gate/fence was damaged/tampered with & 27.5 & 13.4 \\
\hline Someone seen/heard trying to break in & 40.4 & 19.7 \\
\hline Someone seen acting suspiciously & 22.2 & 10.8 \\
\hline $\begin{array}{c}\text { Other: Includes where burglar alarm went off, someone tried to enter using false } \\
\text { pretences, and other evidence. }\end{array}$ & 27.2 & 13.2 \\
\hline \multicolumn{3}{|l|}{ Burglary } \\
\hline Property damaged & 103.3 & 44.7 \\
\hline Property not damaged & 127.2 & 55.0 \\
\hline
\end{tabular}

${ }^{2}$ More than one type of evidence of attempted break-in may have been specified; therefore, components may not add to total.

(Crime Victimisation, Australia 2017/2018 2019).

by perpetrators without a high degree of organisation. This is mainly because it is relatively easy to break into a flat or a free-standing house. Usually, simple tools are used, such as a screwdriver, to pry open the relevant windows or doors. In addition, one stone is often sufficient to break through the windowpane and enter a house (Wollinger et al. 2018). A special feature of this study is that the aspect of international cooperation was taken into account by conducting interviews with 17 police officers from Albania, Croatia, Lithuania, Austria, the Republic of Moldova and Romania, in addition to the interviews in Germany. The countries were selected based on the extent of their relevance to German investigative authorities, because perpetrators come from these countries or, as in the case of Austria, the situation is similar to that of Germany. Although violent crime is of particular concern in Brazil, with rates exceeding those of many Western countries, Brazil experiences relatively low levels of residential burglary. However, the low residential burglary rate in Brazil is comparable to most rates experienced in other Latin American countries such as Colombia, Mexico, Panama, and Paraguay (United Nations Office on Drugs and Crime 2014).

Because of limited available international data on target hardening measures implemented by residents to mitigate property crimes, and particularly limited available data on methods of entry and accompanying force used and damage caused by burglars to gain access to victims' properties, the author provides the following synopsis to further illustrate the force used, and destruction caused by burglars to gain entry to victims' properties as generally experienced in South Africa. This synopsis is not necessarily limited to residential burglary but includes burglary of business premises, government buildings and schools to illustrate the forceful and destructive conduct of burglars in South Africa.

Ngobeni (2019) emphasises that the destruction of property and theft of personal property have increased significantly across South Africa. An increase in residential burglaries of 18.4 percent in Pietermaritzburg and a staggering increase of 42.2 percent in Estcourt, KwaZulu-Natal (KZN) province, prompted residents to purchase non-lethal weapons, such as paintball guns and air-rifles, for self-protection purposes (Umraw 2015). Mngoma (2016) reported on burglars who gained access to schools in KZN through the roof and used an angle grinder to cut open the strongroom and safes. To further illustrate the extent of, and forceful, destructive conduct, which burglars are prepared to take, three suspects were found in possession of suspected stolen property and a hand grenade in Excelsior in the Free State province (Semela 2017). Dawood (2018) further illustrates South African burglars' destructive conduct reporting on Chatsworth residents in KZN. Several of these residents' homes had been burgled on numerous occasions. Despite most of these homes having highperimeter walls fitted with razor wire, it has not deterred burglars. One resident's palisade perimeter fencing steel bars were removed and his home burgled. After 
this incident, he added an additional row of razor wire at the bottom of the fence. In addition, Naidoo (2020) reported during a South African Broadcasting Corporation (SABC) News report that burglars in the West Rand of Gauteng province were making holes in boundary walls to gain entry to premises. This method of entry to victims' properties, as reported in the news report, correlates with the findings on the destructive conduct of burglars in the selected neighbourhood to overcome intensified target hardening measures as illustrated in paragraph 7.2.2 below. Lebuso (2018) further reports on citizens' fear of burglaries and the subsequent measures residents in Dube, Orlando and Meadowlands in Soweto had to take to protect themselves and their property. To further illustrate the bold and destructive nature of burglars in South Africa, burglars gained access to the Alexandra Road police station in Pietermaritzburg in KZN province by breaking a hole on the wall after which they burgled the police station (No repairs yet after break-in 2017). Crimes such as burglaries have reached such high levels in the Tshwane Metropolitan area that it is compared to New York city of old (Mudzuli 2018). The Landsdowne and Rondebosch East neighbourhood watch in Cape Town reported that residents were arming themselves against an alarming increase in attacks by burglary gangs who smash their way into homes using crowbars (Dolley 2015). This concise overview illustrating the force used and destruction caused by burglars to gain access to properties represents Gauteng, KwaZuluNatal, Free State and the Western Cape provinces. As illustrated in the SAPS Annual Crime Statistics for $2016 / 2017$, several provinces are represented in the "worst 10" list which had the most residential burglary incidences, including Mpumalanga, Gauteng, KwaZuluNatal, North West, Limpopo and the Western Cape (South Africa 2017). In addition, according to the Victims of Crime Survey 2019/2020, in terms of settlement type, households in urban areas were more likely to experience housebreaking (South Africa 2020c).

The above-illustrated data on target hardening measures implemented to mitigate property crimes internationally and data on methods of entry, and accompanying force used, and damage caused by burglars to gain access to victims' properties, can serve as the basis for making cross-country comparisons. It could thus further be inferred that exposure to a residential burglary in South Africa is fairly evenly distributed and the degree of force and destruction used by burglars to overcome target hardening measures is similar across most neighbourhoods in the country.

\section{METHODOLOGY}

This study followed a qualitative research approach. A case study design was used and focussed on nonviolent property crime victimisation in the Roodekrans urban residential neighbourhood. Data was gathered from a data set of $(n=3153)$ non-violent property crime victimisation incidences recorded by the neighbourhood watch scheme of the selected neighbourhood between June 2011 and February 2015. Non-probability sampling was used by purposively including incidences categorised as nonviolent property crimes as inclusion criteria resulting in a data set of $(n=1431)$ crimes. A mixed-methods approach was applied to collate the data set of this study by means of qualitative and quantitative content analysis. Approval for the research was granted by the Ethics Committee of the University of South Africa.

The Roodekrans neighbourhood was selected as the sample for inclusion in this study for the following reasons: (1) the neighbourhood is continuously subjected to incidents of non-violent property crime victimisation; (2) residential properties are characterised by various target hardening measures, offering an opportunity to examine the levels of force and destruction used to access victims' properties, and (3) reported non-violent property crime victimisations were meticulously recorded and described by the selected area's neighbourhood watch scheme. The neighbourhood is a middle- to upper-income residential suburb mainly characterised by stand-alone, singlefamily houses. Physical barriers such as metal burglarproof covering windows and steel gates, high outer perimeter fences and gates with electrified fencing or barbed wire, typically characterise houses in this neighbourhood. The residential suburb of Roodekrans is situated in Gauteng province within the City of Johannesburg Metropolitan Municipality and approximately 32 kilometres west of Johannesburg. The suburb covers an area of 4.19 square kilometre with a population of 6457 (South Africa 2011).

\section{RESULTS AND DISCUSSION}

\subsection{Nature and Extent of Predominantly Non- Violent Property Crime Victimisation Incidences}

The predominantly non-violent property crimes reported in the neighbourhood were residential burglary (699 incidents - 49 percent), followed by attempted burglary (346 incidents - 24 percent), theft of motor vehicles and motorcycles (128 incidents -9 percent), 
theft out of motor vehicles (105 incidents -7 percent), attempted theft of motor vehicles and motorcycles (84 incidents -6 percent) and common theft (69 incidents -5 percent).

Similar to the predominantly non-violent property crimes reported in the selected neighbourhood have various authors acknowledged property crimes as the major type of crime worldwide (Sheu and Chiu 2012; Mustaine and Tewksbury 1998; Fox and Farrington 2012; Bond and Hajjar 2013). These findings are in accordance with the most predominant property crimes affecting South African households, as published in the Annual Crime Statistics for 2019/2020 (South Africa 2020a), 2018/2019 (South Africa 2019a) and 2017/2018 (South Africa 2018), as confirmed by the South African Police Service (SAPS) as burglaries at residential premises; theft of motor vehicles and motorcycles, and theft out of or from motor vehicles. Similarly, the 2019/2020 Victims of Crime Survey (VOCS) (South Africa 2020b), estimated 1,2 million incidences of residential burglary occurred, affecting 891000 households in South Africa. The number of affected households represents 5,3 percent of all households in the country. Almost 52 percent of households that experienced residential burglary reported it to the police. Burglary continued to be the dominant type of crime in 2017/18, accounting for 54 percent of all household crimes surveyed in the VOCS. An estimated 832122 incidences of burglary occurred, which is a 7 percent increase compared to the previous year (South Africa 2018).

\subsection{Degree of Force, Destruction and Violence Used by Offenders: Method of Entry to Victims' Properties and Elimination of Threats}

From the analysis, the most popular modes of gaining access to victims' properties and the elimination of potential threats used by offenders were:

\subsubsection{Poisoning/killing of Watchdogs}

Poisoning and/or killing of watchdogs accounted for 74 incidents. Offenders poison dogs mainly to eliminate barking that acts as an early warning to victims and not necessarily the threat of being attacked. In instances when dogs are not poisoned, offenders do not hesitate to physically attack dogs that may be a threat or could announce their presence once they have gained entry to a property.

\subsubsection{Destruction of Property}

Offenders do not hesitate to cause destruction to victims' property to gain access. One would think that intensified target hardening measures that households have taken to mitigate property crimes would make it too difficult and risky for the average offender to continue with these crimes. However, the analysis indicates that offenders do not shy away from excessive use of force to overcome such measures and often cause severe destruction to property in gaining access. As a result, in preparation for conquering target hardening measures, offenders are usually in possession of the necessary equipment to destruct property to gain access. From the analysis, the following destructive methods were mainly used to gain access to property:

- $\quad$ Breaking steel security gates open and removing burglar bars with heavy-duty housebreaking tools such as crowbars (389 incidents). In many instances, security gates were completely detached from walls.

- $\quad$ Cutting electrified perimeter fences, destruction of steel palisade fences, damaging perimeter gates and electrified gate motors (111 incidents). However, a more forceful method used to gain access to the property to take note of is by way of bluntly breaking through precast concrete perimeter walls. This forceful method eliminates electrified fencing attached to the top of these walls.

- $\quad$ Grinding open safes to access firearms, cash or other valuable items ( 3 incidents). In one instance, explosives were found at the scene, most probably to blow open the safe to gain access in case anything else failed.

Various authors confirmed target hardening has been employed internationally and has been widely cited as an effective strategy for burglary reduction (Bond and Hajjar 2013; Weisel 2002; Hirschfield 2004; Millie and Hough 2004; Hamilton-Smith \& Kent 2005; Newton et al. 2008). Sanders et al. 2017 are of the view that although deliberate burglars are more likely to engage in creative techniques and use tools during their burglary, more often than not they will avoid unnecessary risks and attempt to locate a target with fewer obstacles to overcome. In accordance with Sanders et al., the Portland State University (2010), view a burglar's selection of potential targets also reflects his or her desire to find the most accessible dwelling with easy entry and exit. Sorensen (2003) is of the view that restricting access to the perimeter of a property could be expected to reduce the risk of 
burglary since it increases an offender's perceptions of the effort required to access the property itself.

In contrast to the reviewed literature, it was found that offenders in the sampled neighbourhood do not hesitate to cause destruction to victims' property to overcome target hardening measures and gain access. It was further found that the difficulty and risk associated with intensified target hardening measures that households have taken to mitigate property crimes in the sampled neighbourhood do not deter offenders from excessive use of force to overcome such measures and often cause severe destruction to property in gaining access.

Cross-country comparisons of excessive force and destruction caused by burglars to gain access to victims' properties in the execution of residential burglary, as illustrated in paragraph 4 above, provided insight into the methods of entry used by burglars, how physical measures were overcome or attempted to overcome, force and violence used, and the destruction caused by burglars to gain access to victims' properties in these countries. Semela (2017), Dawood (2018), Mngoma (2016) and Naidoo (2020) further illustrate the extent of, and forceful, destructive conduct of burglars in South Africa. These authors, for example, reported on suspected burglars who were found in possession of a hand grenade, burglars who gained access to schools through the roofs and used an angle grinder to cut open strongrooms and safes, repeated burglaries despite of homes having high-perimeter walls fitted with razor wire, and palisade perimeter fencing steel bars that were cut off and home burgled.

The results from these cross-country comparisons evidently illustrate that the degree of force used and damage caused in the execution of residential burglary in the sampled neighbourhood is more forceful and destructive than residential burglaries in those international countries reviewed.

Data on target hardening measures implemented to mitigate property crimes in the selected neighbourhood as well as international data on methods of entry, accompanying force used and damage caused by burglars to gain entry to victims' properties, served as the basis for making cross-country comparisons. From these comparisons, it is evident that the degree of force used and damage caused in the execution of residential burglary in the sampled neighbourhood is more forceful and destructive than residential burglaries in countries reviewed, including Namibia,
Swaziland, Lesotho, Mozambique, Zambia, Zimbabwe, Uganda, England and Wales, Australia, Albania, Croatia, Lithuania, Austria, the Republic of Moldova, Romania, the cities Berlin, Bremerhaven, Hannover, Munich and Stuttgart in Germany, North Carolina in the USA, and Latin American countries such as Brazil, Colombia, Mexico, Panama, and Paraguay. These comparisons, therefore, provide improved insight to judge the degree of force used and destruction caused by South African offenders in the execution of residential burglary in urban residential neighbourhoods.

The findings from this study, in contrast to the reviewed literature, found that South African burglars do not avoid unnecessary risks nor do they necessarily attempt to locate a target with fewer obstacles to overcome. Moreover, the selection of potential targets by burglars in South Africa do not reflect his or her desire to find the most accessible dwelling with easy entry and exit. Although target hardening has substantial evidence, confirming its effectiveness has the findings of this study proven different, for example, restricting access to the perimeter of a property does not reduce the risk of burglary, since such measure does not necessarily increase a burglar's perceptions of the effort required to access the property. The findings of this study suggest that the increased effort needed by an offender to commit non-violent property crime in South Africa, as a result of intensified target hardening preventive measures implemented by the vast majority of households due to widespread and recurring property crime victimisation, in effect, motivates perpetrators to resort to radical use of force and destruction to gain access to victims' properties in order to overcome reinforced target hardening measures.

The findings from this study are therefore of particular significance since it provides a unique understanding of the degree of force used and destruction caused by South African offenders in the execution of residential burglary in urban residential neighbourhoods as compared to various countries internationally. These findings contribute to new knowledge with regard to target hardening measures implemented by households to mitigate residential burglary. Consequently, these findings bridge the research gaps by providing new insights, and question, current theories on target hardening and its effectiveness with regard to residential burglary as well as target selection of a property versus risks. 


\section{CONCLUSION}

This paper reported on the excessive use of force and destruction caused by offenders to gain entry to victims' properties in the execution of residential burglary in South Africa, resulting in the following interpretations:

1. Offenders who commit residential burglary in the selected neighbourhood, are uncharacteristically forceful and ravage in their actions since they frequently revert to extreme use of force and destruction "disproportionate" to the crime perpetrated.

2. The radical degree of force used, and destruction caused by offenders to gain entry to victims' properties in the execution of residential burglary is not typically associated with residential burglary as compared to countries internationally.

3. Target hardening measures are customary among South African households as a deterrent against offenders committing residential burglary. However, burglars are, to a great extent, not discouraged by these intensified measures and do not shy away from using excessive force and destruction to overcome such measures.

4. The forceful and destructive nature of residential burglary in South Africa greatly contributes to the fear of crime.

Countries globally are challenged with non-violent property crime victimisation, in particular residential burglary, which is generally characterised by some use of force and damage. However, the degree of force used, and destruction caused by burglars to gain entry to victims' properties accompanying the execution of these crimes vary among countries.

\section{ACKNOWLEDGEMENTS}

The author would like to thank the Roodekrans Neighbourhood Watch for providing the property crime victimisation statistics used in this paper. The financial assistance from the University of South Africa, College of Law Research and Innovation Fund to present this paper at the International Police Executive Symposium 27th Annual Meeting in Washington, DC, USA, is acknowledged.

\section{REFERENCES}

Adzande, P. and Gyuse, T.T. 2017. "Territoriality and Safety in Urban Residential Neighbourhoods in Nigeria." Urbanism: International Research on Placemaking and Urban Sustainability, 10(3):333-355. https://doi.org/10.1080/17549175.2017.1295095

Altbeker, A. 2005. "Puzzling Statistics: Is South Africa Really the World's Crime Capital?" SA Crime Quarterly, 11:1-8.

Bennett, R. R. 1991. "Routine Activities: A Cross-National Assessment of a Criminological Perspective." Social Forces, 70:147-163. https://doi.org/10.2307/2580066

Bond, B.J. and Hajjar, L.M. 2013. "Measuring Congruence between Property Crime Problems and Response Strategies: Enhancing the Problem-solving Process." Police Quarterly, 16:323-338. https://doi.org/10.1177/1098611113497041

Brunton-Smith, I. and Sturgis, P. 2011. "Do Neighborhoods Generate Fear of Crime? An Empirical Test Using the British Crime Survey." Criminology, 49:331-369. https://doi.org/10.1111/j.1745-9125.2011.00228.x

Centre for the Study of Violence and Reconciliation. 2007. The violent nature of crime in South Africa. A concept paper for the Justice, Crime Prevention and Security Cluster (p. 48). Johannesburg: Centre for the Study of Violence and Reconciliation.

Chon, D.S. and Wilson, M. 2016. "Perceived Risk of Burglary and Fear of Crime: Individual-and Country-level Mixed Modeling." International Journal of Offender Therapy and Comparative Criminology, 60:308-325. https://doi.org/10.1177/0306624X14551257

Clarke, R. V. G. 1997. Situational Crime Prevention: Successful Case Studies. 2nd ed. Albany, NY: Harrow and Heston.

Clarke, R. V. and Homel, R. 1997. "A Revised Classification of Situational Crime Prevention Techniques." Pp. 17-27 in Crime Prevention at a Crossroads, edited by S. P. Lab. Cincinnati: Anderson Publishing Co.

Cornish, D. and Clarke, R. 2003. "Opportunities, Precipitators, and Criminal Decisions: A Reply to Wortley's Critique of Situational Crime Prevention." Pp. 41-96 in Theory for Practice in Situational Crime Prevention, edited by M. Smith and D. Cornish. Monsey, NY: Criminal Justice Press.

Crime Survey for England and Wales 2008-2018. 2019. Nature of Crime: burglary. London: Office for National Statistics.

Crime Victimisation, Australia 2017/2018. 2019. Canberra: Australia Bureau of Statistics.

Cromwell, P. F., Olson, J.N, and Avary, D.W. 1991. Breaking and Entering: An Ethnographic Analysis of Burglary. Newbury Park, CA: Sage.

Dawood, Z. 2018. "Someone is Watching: Man Arrested with Robbery Notes," Daily News, July 11, p. 1.

Dolley, C. 2015. "Householders Live in Fear as Crowbar Gang Attacks Rise," Sunday Argus, June 7, p. 7.

Dull, R.T. and Wint, A.V.N. 1997. "Criminal Victimization and its Effect on Fear of Crime and Justice Attitudes." Journal of Interpersonal Violence, 12(5):748-758.

Edmark, K. 2005. "Unemployment and Crime: Is there a Connection?" Scandinavian Journal of Economics, 107:353373. https://doi.org/10.1111/j.1467-9442.2005.00412.x

Estrada, F. and Nilsson, A. 2008. "Segregation and Victimization: Neighbourhood Resources, Individual Risk Factors and Exposure to Property Crime." European Journal of Criminology, 5:193-216. https://doi.org/10.1177/1477370807087642

Ferraro, K. 1995. Fear of Crime: Interpreting Victimization Risk Albany: State University of New York Press. 
Fox, B.H. and Farrington, D.P. 2012. "Creating Burglary Profiles Using Latent Class Analysis: A New Approach to Offender Profiling." Criminal Justice and Behavior, 39:1582-1611. https://doi.org/10.1177/0093854812457921

Gallup Global Law and Order 2015 Report. 2015. Washington, D.C.

Gould, C. 2014. Comment: Why is Crime and Violence so High in South Africa? Retrieved August 9, 2016 (https://africacheck.org/2014/09/17/comment-why-is-crimeand-violence-so-high-in-south-africa-2/).

Grabosky, P.N. 1995. "Burglary Prevention." Trends and Issues in Criminal Justice, 49:1-6. Retrieved February 14, 2021 (https://www.aic.gov.au/sites/default/files/202005/tandi049.pdf).

Hale, C. 1996. "Fear of Crime: A Review of the Literature." International Review of Victimology, 4:79-150. https://doi.org/10.1177/026975809600400201

Hamilton-Smith, N. and Kent, A. 2005. The Prevention of Domestic Burglary. In N. Tilley (Ed.), Handbook of Crime Prevention and Community Safety (pp. 417-457). Cullompton, Devon: Willan Publishing.

Hirschfield, A. 2004. The Impact of the Reducing Burglary Initiative in the North of England, Home Office Online Report 40/04, London: Home Office.

Indermaur, D. 1996. Reducing the Opportunities for Violence in Robbery and Property Crime: The Perspectives of Offenders and Victims. Crime Research Centre. University of Western Australia, Nedlands, Western Australia.

Institute for Economics \& Peace (IEP). 2015. Positive Peace Report 2015. New York, USA.

Jackson, J. 2006. "Introducing Fear of Crime to Risk Research." Risk Analysis, 26:253-264. https://doi.org/10.1111/j.1539-6924.2006.00715.x

Kleck, G. and Chiricos, T. 2002. "Unemployment and Property Crime: A Target-specific Assessment of Opportunity and Motivation as Mediating Factors." Criminology, 40:649. https://doi.org/10.1111/j.1745-9125.2002.tb00969.x

Kuhns, J.B, Blevins, K.R., and Turner, M.G. 2016. Charlotte Residential Burglary Victimization Survey: Exploring Postburglary Adaption from a Victim's Perspective. The University of North Carolina at Charlotte Department of Criminal Justice \& Criminology, Charlotte, USA: University of North Carolina at Charlotte.

Kuo, S. 2015. Opportunity, Choice, and Burglary Victimization in Taiwan. International Journal of Offender Therapy and Comparative Criminology, 59:873-891. https://doi.org/10.1177/0306624X13520439

Ladikos, A. 2006. "Household Victimization Rates". Pp. 29-40 in Experiences of Crime in Thirteen African Countries: Results from the International Crime Victim Survey, edited by C.M.B. Naudé, J.H. Prinsloo \& A. Ladikos. Turin: UNICRI-UNODC.

Lane, J. and Fox, K.A. 2013. "Fear of Property, Violent, and Gang Crime: Examining the Shadow of Sexual Assault Thesis among Male and Female offenders." Criminal Justice and Behavior, 40:472-496. https://doi.org/10.1177/0093854812463564

Larsson, D. 2009. "Fear of Crime among the Poor in Britain and Sweden." International Review of Victimology, 15:223-254. https://doi.org/10.1177/026975800901500302

Lebuso, A. 2018. 'Save us from criminals' plea. Daily Sun, August 14, p. 4.

Markowitz, F.E., Bellair, P.E., Liska, A.E., and Liu, J. 2001. "Extending Social Disorganization Theory: Modeling the Relationships between Cohesion, Disorder, and Fear." Criminology, 39:293-320.

https://doi.org/10.1111/j.1745-9125.2001.tb00924.x

Millie, A. and Hough, M. 2004. Assessing the Impact of the Reducing Burglary Initiative in Southern England and Wales, Home Office Online Report 42/04, London: Home Office.
Mngoma, N. 2016. "Gadget Gang Hits KZN: 20 Schools Burgled in Just 4 Months," Daily News, April 19, p. 1.

Mudzuli, K. 2018. "Tshwane is on the Crime Warpath," Pretoria News, February 5, p. 7.

Mustaine, E.E. and Tewksbury, R. 1998. "Predicting Risks of Larceny Theft Victimization: A Routine Activity Analysis Using Refined Lifestyle Measures." Criminology, 36:830-58. https://doi.org/10.1111/j.1745-9125.1998.tb01267.x

Naidoo, S. 2020. Criminals are Using New Burglary Tactics. SABC News. Retrieved January 25, 2020 (https://www.sabcnews.com/sabcnews/criminals-are-usingnew-burglary-tactics/).

Newton, A., Rogerson, M., and Hirschfield, A. 2008. Relating Target Hardening to Burglary Risk: Experiences from Liverpool. Papers from the British Criminology Conference, 8. pp. 153174.

Ngobeni, L. 2019. "Damage to Property on the Rise," Daily News, October 4, p. 4

Nilsson, A. and Agell, J. 2003. Crime, Unemployment and Labor Market Programs in Turbulent Times. Working Paper nr. 14, Institute for Labor Market Policy Evaluation, Uppsala.

No Repairs yet after Break-in. 2017. The Witness, December 19, $p$. 4.

Owusu, G., Wrigley-Asante, C., Oteng-Ababio, M., and Owusu, A.A 2015. Urban Crime Prevention and Community Social Cohesion: The case of urban Ghana. Policy Brief, nr.2 August 2015. Institute of Statistical, Social and Economic Research (ISSER), University of Ghana, Legon.

Pitcher, A.B. and Johnson, S.D. 2011. "Exploring Theories of Victimization using a Mathematical Model of Burglary." Journal of Research in Crime and Delinquency, 48:83-109. https://doi.org/10.1177/0022427810384139

Portland State University. 2010. "Criminology and Criminal Justice Senior Capstone. Prevention of Residential Burglary: A review of the Literature." Criminology and Criminal Justice Senior Capstone Project. Paper 3. Retrieved October 9, 2018 (http://pdxscholar.library.pdx.edu/ccj_capstone/3).

Robinson, M. B. and Robinson, C.E. 1997. "Environmental Characteristics Associated with Residential Burglaries of Student Apartment Complexes." Environment \& Behavior, 29(5):657-675

Roh, S., Kim, E., and Yun, M. 2010. "Criminal Victimization in South Korea: A Multilevel Approach." Journal of Criminal Justice, 38:301-310. https://doi.org/10.1016/j.jcrimjus.2010.03.004

Rountree, P. and Land, K. 1996. "Burglary Victimization, Perceptions of Crime Risk, and Routine Activities: A Multilevel Analysis across Seattle Neighborhoods and Census Tracts." Journal of Research in Crime \& Delinquency, 33:147-180. https://doi.org.10.1177/0022427896033002001

SA's Violent Crime has Roots in Apartheid, says Report. 2011 Centre for the Study of Violence and Reconciliation. $\begin{array}{lll}\text { Retrieved August } & 12, & \end{array}$ (http://www.sanews.gov.za/features/sas-violent-crime-hasroots-apartheid-says-report).

Sanders, A.N., Kuhns, J.B., and Blevins, K.R. 2017. "Exploring and Understanding Differences between Deliberate and Impulsive Male and Female Burglars." Crime \& Delinquency, 63(12):1-25. https://doi.org/10.1177/0011128716660519

Semela, B. 2017. "Hand Grenade Found after Burglary," The New Age, April 18, p. 8.

Sheu, C. and Chiu, S. 2012. "Determinants of Property Crime Victims to Report to the Police in Taiwan." International Review of Victimology, 18(3):251-267. https://doi.org/10.1177/0269758012446986

Sims, B., Yost, B., and Abbott, C. 2006. "The Efficacy of Victim Services Programs. Alleviating the Psychological Suffering of 
Crime Victims?" Criminal Justice Policy Review, 17(4):387406.

https://doi.org/10.1177/0887403406290656

Skogan, W. 1987. "The impact of victimization on fear." Crime \& Delinquency, 33(1):135-154. https://doi.org/10.1177/0011128787033001008

Sorensen, D.W.M. 2003. The Nature and Prevention of Residential Burglary: A Review of the International Literature with an Eye toward Prevention in Denmark. Copenhagen: Denmark Ministry of Justice.

South Africa. 2011. Census 2011. Statistics South Africa. Pretoria: Government Printer.

South Africa. 2014. Statistics South Africa. 2013/14 Victims of Crime Survey (VOCS). Pretoria: Statistics South Africa.

South Africa. 2018. Statistics South Africa. 2017/18 Victims of Crime Survey (VOCS). Pretoria: Statistics South Africa.

South Africa. 2015. South African Police Service. Annual Report 2014/2015. Pretoria: National Commissioner.

South Africa. 2017. South African Police Service Annual Crime Statistics for 2016/2017. Pretoria: Statistics South Africa.

South Africa. 2018. South African Police Service Annual Crime Statistics for 2017/2018. Pretoria: Statistics South Africa.

South Africa. 2019a. South African Police Service Annual Crime Statistics for 2018/2019. Pretoria: Statistics South Africa.

South Africa. 2020a. South African Police Service Annual Crime Statistics for 2019/2020. Pretoria: Statistics South Africa.

South Africa. 2019b. Statistics South Africa. 2018/19 Victims of Crime Survey (VOCS). Pretoria: Statistics South Africa.

South Africa. 2020b. Statistics South Africa. 2018/19 Victims of Crime Survey (VOCS). Pretoria: Statistics South Africa.

South Africa. 2020c. Statistics South Africa. 2019/20 Victims of Crime Survey (VOCS). Pretoria: Statistics South Africa.

South Africa. 2020d. Statistics South Africa. Quarterly Labour Force Survey (QLFS) - Q1: 2020. Pretoria: Statistics South Africa.

Stein, R.E. 2010. "The utility of country structure: A cross-national multilevel analysis of property and violent victimization." International Criminal Justice Review, 20(1):35-55. https://doi.org/10.1177/1057567710361718

Tseloni, A. 2006. "Multilevel Modelling of the Number of Property Crimes: Household and Area Effects." Journal of the Royal Statistical Society, series A-statistics in Society, 169(2):205233. https://doi.org/10.1111/j.1467-985X.2005.00388.x

Tseloni, A. and Farrell, G. 2002. Burglary Victimization across Europe: The Roles of Prior Victimization, Micro and Macrolevel Routine Activities. In P. Nieuwbeerta (Ed.), Crime Victimisation in Comparative Perspective: Results from the International Crime Victims Survey, 1989-2000. (pp. 141161). Boom.

Trickett, A., Osborn, D.R., and Ellingworth, D. 1995. "Property Crime Victimisation: The Roles of Individual and Area Influences." International Review of Victimology, 3(4):273-295. https://doi.org/10.1177/026975809500300402
Umraw, A. 2015. "Self-protection Spree: Scared KZN Citizens Stock up on Non-lethal Weapons," Weekend Witness, October 3, p. 5.

United Nations Office on Drugs and Crime. 2014. UNODC International

Burglary, Car Theft and Housebreaking Statistics. Retrieved January 23, $2021 \quad$ (https://www.unodc.org/unodc/en/data-andnalysis/statistics/data.html).

U.S. Department of Justice. 2013. Uniform Crime Report Crime in the United States, 2013. Washington, DC: U.S. Department of Justice, Federal Bureau of Investigation.

Van Wilsem, J., de Graaff, N.D., and Wittebrood, K. 2003. "Crossnational Differences in Victimization: Disentangling the Impact of Composition and Context." European Sociological Review, 19(2):125-142. https://doi.org/10.1093/esr/19.2.125

Victimization Survey in Egypt. Executive Summary. 2009. Vienna, Austria: Ghana Statistical Service in collaboration with the United Nations Office on Drugs and Crime (UNODC).

Victimization Survey in Ghana. Executive Summary. 2010. Vienna, Austria: Ghana Statistical Service in collaboration with the United Nations Office on Drugs and Crime (UNODC).

Victimization Survey in Kenya. Executive Summary. 2010. Vienna, Austria: Ghana Statistical Service in collaboration with the United Nations Office on Drugs and Crime (UNODC).

Victimization Survey in Tanzania. Executive Summary. 2009. Vienna, Austria: Ghana Statistical Service in collaboration with the United Nations Office on Drugs and Crime (UNODC).

Victimization Survey in Uganda. Executive Summary. 2008. Vienna, Austria: Ghana Statistical Service in collaboration with the United Nations Office on Drugs and Crime (UNODC).

Vogelman, L. \& Simpson, G. 1990. Current Violence in South Africa, Research Paper, Centre for the Study of Violence and Reconciliation, June 1990.

Weisel, D. 2002. Burglary of Single-family Houses, Problem-oriented Guides for Police Series No. 18, Washington, DC: Department of Justice, Office of Community Oriented Policing Services.

Wollinger, G., Dreißigacker, A., and Baier, D. 2017. "Residential Burglary: Main Results of a Study in Germany." Sociology and Criminology, 15(1). https://doi.org.10.4172/2375-4435.1000161

Wollinger, G.R., Querbach, M., Röhrig, A., König, A., and Isenhardt, A. 2018. Offender Organization and Criminal Investigations with regard to Organised Residential Burglary: Results of an International Expert Survey. Research Report No 147. Kriminologisches Forschungsinstitut Niedersachsen e.V. (KFN): Hannover, Germany.

Wortley, R. 2001. "A Classification of Techniques for Controlling Situational Precipitators of Crime." Security Journal, 14:6382.

https://doi.org/10.1057/palgrave.s].8340098

Received on 13-03-2021

https://doi.org/10.6000/1929-4409.2021.10.117

(C) 2021 Johan van Graan; Licensee Lifescience Global.

This is an open access article licensed under the terms of the Creative Commons Attribution Non-Commercial License (http://creativecommons.org/licenses/by-nc/3.0/) which permits unrestricted, non-commercial use, distribution and reproduction in any medium, provided the work is properly cited. 